\section{Reply: Concerns with the use of Genelyn cadavers for surgical simulation}

Sir,

Thank you for your comments. You question our statement on the softness and pliability quoting a review article which contains that single statement quoted in the article as it being stiff and lacking colour. There is no dispute regarding this - Genelyn preserved tissue is and will not be fresh in frozen cadavers. Of course, there will be a lack of colour. As reconstructive microsurgeons, we find the dissection of such tissue suitable to our needs. Reasonably, other authors may have other opinions and are entitled to their respective subjective statements. Unless we find some method of quantifying pliability of tissues according to simulation needs, there will be no consensus.

We did not find surgical planes obscured as you mention in your letter. This would depend on your fixation technique again and we cannot be sure that the methods are similar across each study. In our hands, this technique provides a suitable simulation model and there are no issues with regard to surgical planes which should allay your concerns in the third paragraph.

Your concerns with regard to mould and cost-effectiveness again depend on your resources and need. If your unit is flush with resources, by all means, consider other forms of tissue preservation. We provide an alternative method of simulation considering costs but your points are noted. Mould should not be an issue; we only use these cadavers for surgical practice and not permanent fixation. Other forms of tissue preservation should be considered if these cadavers are to be kept for longer periods of time.

We would like to remind the authors that sensory feedback, albeit it important, to us as reconstructive microsurgeons, is not the only aspect in flap raising. Much of the flap raising is visual and rather than blind dissection which involves the use of sensory cues, flap raising in our opinion should be performed under direct vision of the vessels to reduce any inadvertent pedicle injury. Bear in mind, we do not handle any vessel directly to prevent any inadvertent injury to the pedicle. We simulate the steps in flap raising and acknowledge your points raised but again, all opinions are subjective. Further evidence regarding methods of evaluating this cadaveric simulation model is required. One could directly compare the effectiveness of Genelyn and Thiel preservation techniques in plastic surgery simulation if interested.

\section{Financial support and sponsorship}

Nil.

\section{Conflicts of interest}

There are no conflicts of interest.

\section{Charles Yuen Yung Loh, Nigel Yong Boon Ng${ }^{1}$, Thanassi Athanassopoulos ${ }^{2}$}

Department of Plastic Surgery, Vascularized Composite Allotransplantation Center, Chang Gung Memorial Hospital, Linkou, Taiwan, Republic of China, ${ }^{1}$ Department of Surgery, Glasgow Royal Infirmary, Glasgow, ${ }^{2}$ Department of Plastic Surgery, Aberdeen Royal Infirmary, Aberdeen, Scotland 
Address for correspondence:

Dr. Charles Yuen Yung Loh,

Chang Gung Memorial Hospital,

No. 5, Fu-Hsing Street,

Guishan, Taoyuan 333,

Taiwan, Republic of China.

E-mail: chloh_yy@hotmail.com

This is an open access article distributed under the terms of the Creative Commons Attribution-NonCommercial-ShareAlike 3.0 License, which allows others to remix, tweak, and build upon the work non-commercially, as long as the author is credited and the new creations are licensed under the identical terms.

\begin{tabular}{|l|l|}
\hline \multicolumn{2}{|c|}{ Access this article online } \\
\hline Quick Response Code: & Website: \\
\hline
\end{tabular}

How to cite this article: Loh CY, Ng NY, Athanassopoulos T. Reply: Concerns with the use of Genelyn cadavers for surgical simulation. Indian J Plast Surg 2016;49:434-5.

() 2016 Indian Journal of Plastic Surgery | Published by Wolters Kluwer - Medknow 